\title{
Habitat Use and Movement Activity of Neolissochilus soroides and Channa lucius during Post Inundation of Tembat Reservoir, Hulu Terengganu
}

\author{
Shazana Sharir ${ }^{1,2}$, Nurfatin Zulkipli ${ }^{2,6}$, Azhari Mohamad ${ }^{2}$, Farah Ayuni \\ Farinordin $^{3}$, Shafiq Zakeyuddin ${ }^{4}$, Abdullah Samat', Amir Shah Ruddin Md Sah \\ and Shukor Md Nor ${ }^{2 *}$
}

${ }^{1}$ Faculty of Fisheries and Food Science, Universiti Malaysia Terengganu, 21300, Kuala Nerus, Terengganu, Malaysia

${ }^{2}$ Faculty of Science and Technology Universiti Kebangsaan Malaysia, 43600 UKM Bangi, Selangor, Malaysia ${ }^{3}$ Faculty of Applied Sciences, Universiti Teknologi MARA (Jengka Campus), 26400 Jengka, Pahang, Malaysia ${ }^{4}$ Tenaga Nasional Berhad Research, Jalan Ayer Itam, 43600 Bangi, Selangor, Malaysia

${ }^{5}$ School of Biological Science, Universiti Sains Malaysia, 11800, Georgetown Pulau Pinang, Malaysia

${ }^{6}$ University of Debrecen, Department of HydrobiologyDebrecen, Hajdú-Bihar, 4032, Hungary

\begin{abstract}
ARTICLE INFO

\section{Article history:}

Received: 27 August 2020

Accepted: 10 June 2021

Published: 20 August 2021

DOI: https://doi.org/10.47836/pjtas.44.3.01

E-mail addresses:

shazana.sharir@umt.edu.my (Shazana Sharir) nurfatinzulkipli93@gmail.com (Nurfatin Zulkipli) azhari.biomaster@gmail.com (Azhari Mohamad) farahayuni2506@uitm.edu.my (Farah Ayuni Farinordin)

shafiq.zakeyuddin@tnb.com.my (Shafiq Zakeyuddin)

nature5283@gmail.com (Abdullah Samat)

amirshah@usm.my (Amir Shah Ruddin Md Sah)

shukor@ukm.my (Shukor Md Nor)

*Corresponding author
\end{abstract}

The drastic changes in hydroelectric reservoir development created a completely new ecosystem that affects the river, particularly in the inundated area. In this study, five Neolissochilus soroides and Channa lucius were surgically implanted with a unique coded acoustic transmitter to observe the habitat utilisation and movement activity in Tembat Reservoir after the inundation process. All of the individuals were released into the transition zone of the reservoir and observed using passive and active acoustic tracking devices from April to December 2018. KruskalWalis test showed no significant difference between the average size of core area for $N$. soroides and C. lucius, $\mathrm{x}^{2}(1)=1.320$, $p=0.251$. The home range also showed a similar result for $N$. soroides and $C$. lucius where there was an insignificant difference, $\mathrm{x}^{2}(1)=0.273, p=0.602$. However, duration wise, $N$. soroides spend more time in the transition zone, R1 ( $\mathrm{M}=2.71 \mathrm{hrs}, \mathrm{SE}=$ 0.38), and C. lucius in the riverine zone, R5 
$(\mathrm{M}=7.14 \mathrm{hrs}, \mathrm{SE}=6.13)$ and $\mathrm{R} 6(\mathrm{M}=3.85$ hours, $\mathrm{SE}=6.36)$. From the active tracking survey, PCA identified three (62.32\%) and four $(71.19 \%)$ components with eigenvalues greater than 1 for $N$. soroides and $C$. lucius, respectively. Three most important habitat parameters for $N$. soroides were the size of river $(r=0.97)$, existence of canopy cover $(r$ $=0.77)$, and substrate type $(r=0.79)$. While, for $C$. lucius were mesohabitat type $(r=$ $0.79)$, distance to riffle $(r=0.97)$, existence of canopy cover $(r=0.90)$, and elevation $(r=0.90)$. A 24-hour movement frequency analysis for both species revealed two active hours of movement at dusk and dawn for both species. From the study, it is known that $N$. soroides and C. lucius respond differently towards the inundation of the reservoir. The findings in this study can be implemented for effective aquatic management and conservation plan to ensure sustainable dam development.

Keywords: Fish movement, fish telemetry, habitat use, hydroelectric impacts, post-inundation

\section{INTRODUCTION}

Inundation of water catchment areas in the tropical rainforest for hydroelectric stations is known to have a devastating effect on the environment. Many studies have described the ecological implications, and the effect is more pronounced in tropical water catchment areas (Fearnside, 2014; Huang \& Li, 2016). These areas are often subject to hydroelectric power development due to geographical landscape and topographic suitability (Zafirah et al., 2017). The construction and pre-impoundment processes, including forest clearing, significantly alter the initial aquatic environment. The most prominent modification is the multidimensional change of the natural water body in the catchment (Zeiringer et al., 2018). The aquatic landscape is usually transformed into an open system with less or no canopy, depending on the volume of the water. It can be divided into three longitudinal systems: riverine (lotic), transition, and lacustrine (lentic) zones (Schmutz \& Moog, 2018). The modification can also involve stratification of the water column in deeper areas where anoxic conditions can occur towards the bottom substrate, making the environment less habitable for aquatic fauna (Kimmel \& Groeger, 1984).

The effects of impoundment on the native river species have gained substantial attention (Kano et al., 2016). In this newly developed lentic habitat, the fish assemblage can be modified qualitatively and quantitively through extermination of native fish species, reduction of habitat diversity, increasing densities of indigenous species, and introducing non-native species (Zhong \& Power, 1996). In addition, the impoundment of downstream areas can influence the fish assemblage through changes in temperature, flow regime, sediment loads, and turbidity of the area (Li et al., 2016). Although in-depth studies of impacts on the ecology of aquatic fauna have been widely discussed, there is still a need to understand more about the utilisation of habitat and movement of fish fauna in a newly inundated riverine system, as this 
subject is poorly documented. Identifying habitat use characteristics and movement patterns is essential for restoring fish fauna and management planning (Clarke et al., 2007).

Neolissochilus soroides is a cyprinid found in Southeast Asia, particularly the Malay Archipelago and Borneo. It is a mahseer species indicative of high altitude, fast-flowing, and excellent water quality (Khaironizam et al., 2015). Channa lucius, or the forest snakehead, is a common species in the Tembat River and found throughout southeast Asia. Unlike other channid species common in peat swamps and stagnant water, C. lucius can be found in fast-flowing clear water at higher altitudes (Ambak et al., 2012). These species are native to Tembat River and a good candidate to represent the black and white water species that may respond to the effect of the inundation differently.

Despite habitat degradation and exploitation being threats to both species, the species are listed as the least concern (LC). Nevertheless, there are currently no published data on the behaviour and movement patterns of these species. Most of the studies conducted on $N$. soroides and $C$. lucius are of their biological and aquaculture potential (Azrita et al., 2015; Khai et al., 2015). The distinctive differences in lifehistory requirements of both species are very important to recognise, especially in identifying areas for biodiversity conservation (Asaad et al., 2017). A mahseer species, such as $N$. soroides, are an umbrella species, which means, protecting its habitat will benefit many other species under its trophic level (Pinder et al., 2019).

While C. Lucius, is widely tolerant to water quality and can be found in a very low $\mathrm{pH}$ environment, this species prefers pristine forested rivers. Moreover, its sedentary characteristics are a great indicator of microenvironmental change (Ambak et al., 2012). This study provides a preliminary assessment of movement pattern and habitat utilisation for both species within Tembat Reservoir. The knowledge acquired from the study of habitat utilisation and movement activity can inform us how the dam developments impact the ichthyofauna of a local river. Nevertheless, this research is intended to be applied in the management of conservation and habitat rehabilitation efforts. Specifically, these preliminary data can aid in establishing protection zones, such as fish sanctuaries or no-take zones.

This study aims to evaluate habitat utilisation and movement activity of $N$. soroides and C. lucius in the transition zone of a small hydroelectric reservoir in the Tembat River system. The specific objectives are: (i) to identify spatial habitat use through the determination of home range and core range area, (ii) to determine environmental variables associated with species detection, (iii) to observe the time spent at different locations within the river, and (iv) to observe the 24-hour movement activity pattern.

\section{MATERIALS AND METHODS}

\section{Study Area}

The study was conducted in the Tembat 
River, Hulu Terengganu, Malaysia, with a pre-experimental study beginning in January 2018 and acoustic tracking conducted from April to December 2018. The Tembat River is part of the Hulu Terengganu Hydroelectric Project (HTHEP), involving approximately $90.834 \mathrm{~km}^{2}$ with two catchment areas: Puah and Tembat (Figure 1). The climate in this area is equatorial monsoon-type, with a high temperature and year-round rainfall. Almost half of the annual rainfall is recorded during November, December, and January, coinciding with the northeast monsoon (Tenaga Nasional Berhad Research [TNBR], 2007). The study was conducted in the transition zone of the Tembat Reservoir, part of the riverine system.

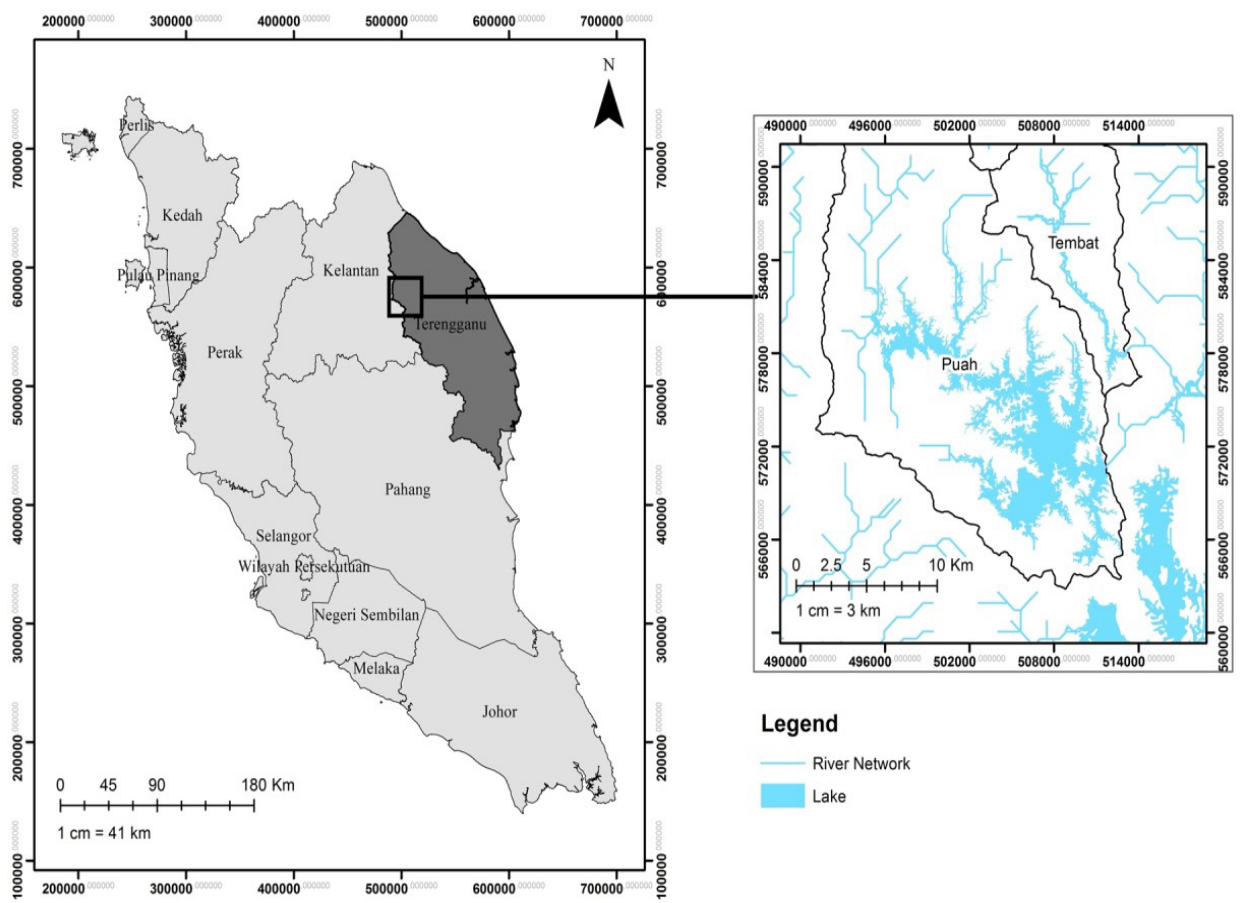

Figure 1. The Tembat Reservoir is located in Tembat catchment Hulu Terengganu, Malaysia which the reservoir is adjacent to the Puah catchment. Both of the catchment is part of Hulu Terengganu Hydroelectric Project (HTHEP)

Fish Capture and Acoustic Transmitter Insertion

Five individuals of $N$. soroides and $C$. lucius were obtained from the Tembat River.
Neolissochilus soroides were captured using traps baited with fermented palm oil kernels in the Tembat River. At the same time, C. lucius were caught by handlines baited with live 
juvenile frogs or were fished using artificial lures and casting techniques. All individuals selected weighed more than $550 \mathrm{~g}$, allowing the $3.7 \mathrm{~g}$ acoustic tag to be safely implanted. The transmitters were $26 \mathrm{~mm}$ long and 9 $\mathrm{mm}$ in diameter. Each of the VEMCO V9 transmitters is uniquely codded so that the passive and active receivers can identify the individuals. Based on Weber et al. (2009), the surgical insertion of the transmitters into the peritoneal cavity was carried out using a modified method. Before surgery, individuals were sedated in a clove oil bath. The surgeries lasted for 10-15 minutes and were performed in a container with continuous irrigation of anaesthetics on the gill. Non-absorbable sutures were used to close the incision, and antibiotics were applied to prevent infections. After the surgery, individuals were kept in a $3 \mathrm{~m} \times 1 \mathrm{~m}$ fibreglass tank with aggressive aeration for immediate recovery progress. Fish were released within the transition zone of the Tembat River on four occasions: 18 April 2018, 19 April 2018, 31 May 2018, and 4 June 2018. The individuals were released back into the river within 14-30 days after the surgery.

\section{Movement and Habitat Utilisation}

Two methods of tracking were used in this study: passive and active tracking. The passive tracking was conducted using six VR2W receivers units deployed within the reservoir. Each receiver station is known as R. VR2W units were placed at $300 \mathrm{~m}$ to $800 \mathrm{~m}$ intervals between each unit in the river. As determined in a preliminary study, the $100 \%$ detection range of VR2W receivers was $66.8 \mathrm{~m}$ from the receiver. The deployment areas include a riverine ( $\mathrm{R} 5$ and R6), transition (R2, R3, R4), and lacustrine zones (R1, R2). The receivers at each location recorded the arrival and departure times of all the uniquely coded IDs of the tagged fish within range, assuming that the signal was unobstructed. The VR2W receivers received pings every 30 seconds from the transmitters in the individuals. The VR2W receivers were deployed underwater for three months (April, May, and June). Data were downloaded using VUE $^{\circledR}$ software (Halifax, Canada).

Active tracking was conducted at least twice each month using VEMCO V100 active tracker and an omnihydrophone. In addition, a single active tracking event was conducted for at least three days from April to December. Active tracking was conducted only during daylight hours as night tracking presents a research limitation as it was unsafe due to active wildlife movement in the Tembat catchment. Tagged individuals were assumed to be within a $5 \mathrm{~m}$ radius of the location detected when the signal strength was at its maximum (i.e. 70-90 dB) (Fetterplace et al., 2016). Ten environmental parameters, as listed in Table 1, were observed during individual detection, and the location coordinate was recorded using a Garmin 64s GPS device (Kansas, United States of America). 
Shazana Sharir, Nurfatin Zulkipli, Azhari Mohamad, Farah Ayuni Farinordin, Shafiq Zakeyuddin, Abdullah Samat, Amir Shah Ruddin Md Sah and Shukor Md Nor

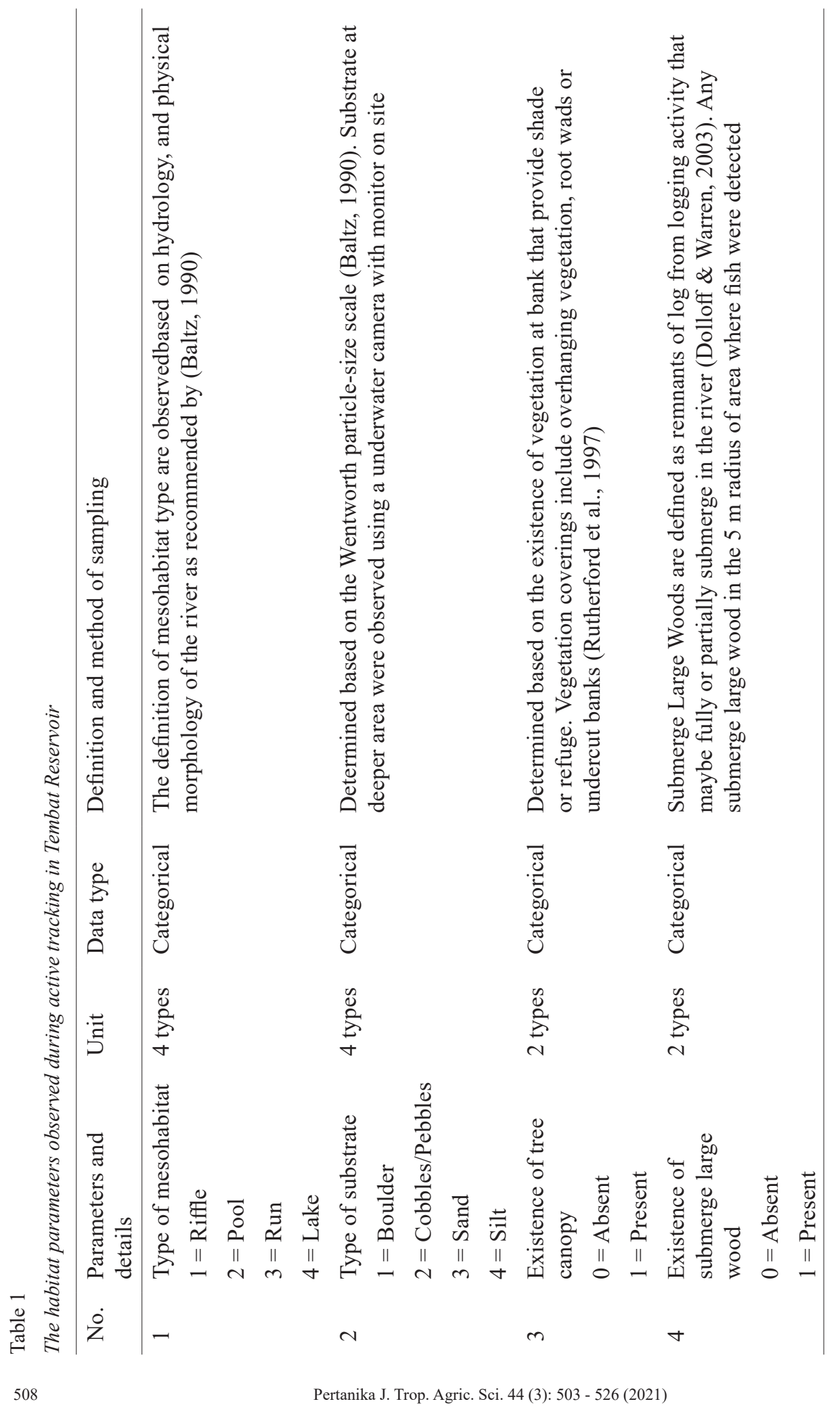


Habitat Use and Movement of Neolissochilus soroides and Channa lucius

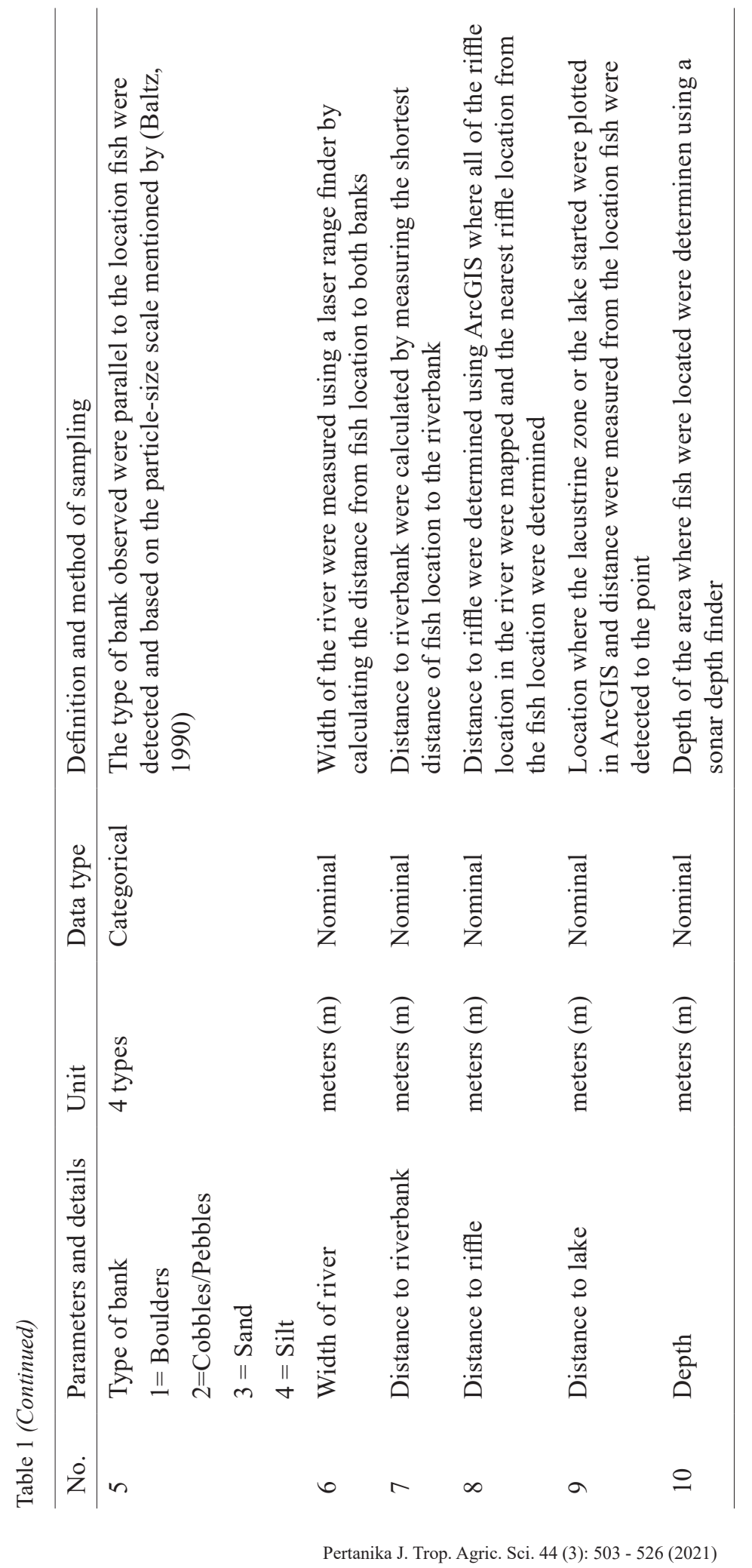


Shazana Sharir, Nurfatin Zulkipli, Azhari Mohamad, Farah Ayuni Farinordin, Shafiq Zakeyuddin, Abdullah Samat, Amir Shah Ruddin Md Sah and Shukor Md Nor

\section{Data Analysis}

Home range size estimations were analysed using the Fishtracker 10.1 toolbox extension in ArcGIS 10.5 software. Fishtracker uses a least-cost path to determine the travel speed between sequential observations and convert it to per-segment travel times (Laffan \& Taylor, 2013). The movement rate was then used in a standard kernel density analysis. In this study, the sequential arrival and departure detection data from each receiver, complemented with active tracking data, provided the substance of the home range estimate. The product of this analysis is a surface area estimate for a home range and a core range.

Individual time spent at each receiver station (R) was observed by analysing the arrival and departure time logged. In addition, the average 24-hour movement activity of $N$. soroides and $C$. lucius was determined using bi-hourly movement count data from VR2W receivers. Active tracking was conducted from April to December simultaneously with passive tracking. During active tracking, ten environmental parameters were observed at every individual location detection. Principal component analysis (PCA) was used to reduce the dimensionality of the environmental variables recorded in this study. Matrices of ten parameters at every location where the individuals were detected using active tracking were constructed for both species to run the PCA. PCA was conducted in Statistical Package for the Social Sciences (SPSS) version 26.0, using varimax rotation with 25 maximum iterations. The Kaiser-Guttman criterion (Guttman, 1954) and the broken-stick criterion (Frontier, 1976) were applied as stopping rules for determining the number of principal components extracted. These rules are based on average test statistic values where eigenvalues that are larger than the average value expected under the null hypothesis are used to assess the relative interpretability of the ordination results. In this study, principal components (PCs), which have eigenvalues greater than one, were considered to represent significant correlations of variance and were extracted (Jackson, 1993). In the rotated component matrix, the highest environmental variables correlation of greater of the component were highly influential.

\section{RESULTS}

\section{Home and Core Range of Neolissochilus soroides and Channa lucius}

All of the individuals in this study were successfully tracked within the river between April and December 2018. The detection span for each individual ranged from 10 days to 244 days. Individual ID 16285 had the shortest detection span, which only lasted for ten days. Therefore, this individual was assumed to be out of the detection range for the rest of the tracking period. The detection span for the rest of the individuals ranged from 193 to 219 days (C. lucius) and 132 days to 244 days (N. soroides).

The 50\% kernel estimation density (KED) core area size of $N$. soroides ranged from $15283 \mathrm{~m}^{2}$ to $86563 \mathrm{~m}^{2}$. (Figure 2), 
while $C$. lucius ranged from $36545 \mathrm{~m}^{2}$ to ranged from $68399 \mathrm{~m}^{2}$ to $161425 \mathrm{~m}^{2}$, which $89578 \mathrm{~m}^{2}$ (Figure 3 ). Kruskal-Wallis test also tested insignificant, $\mathrm{x}^{2}(1)=0.273, p$ conducted to compare the core area size $=0.602$ (Table 2). These results suggest between the species was insignificant, $\mathrm{x}^{2}(1)$ that the home range and core range size $=1.320, p=0.251$. While the $90 \% \mathrm{KED}$ of $C$. lucius and $N$. soroides in the Tembat home range area ranged from $28078 \mathrm{~m}^{2}$ to Reservoir are similar.

$155848 \mathrm{~m}^{2}$ for $N$. soroides, and C. lucius
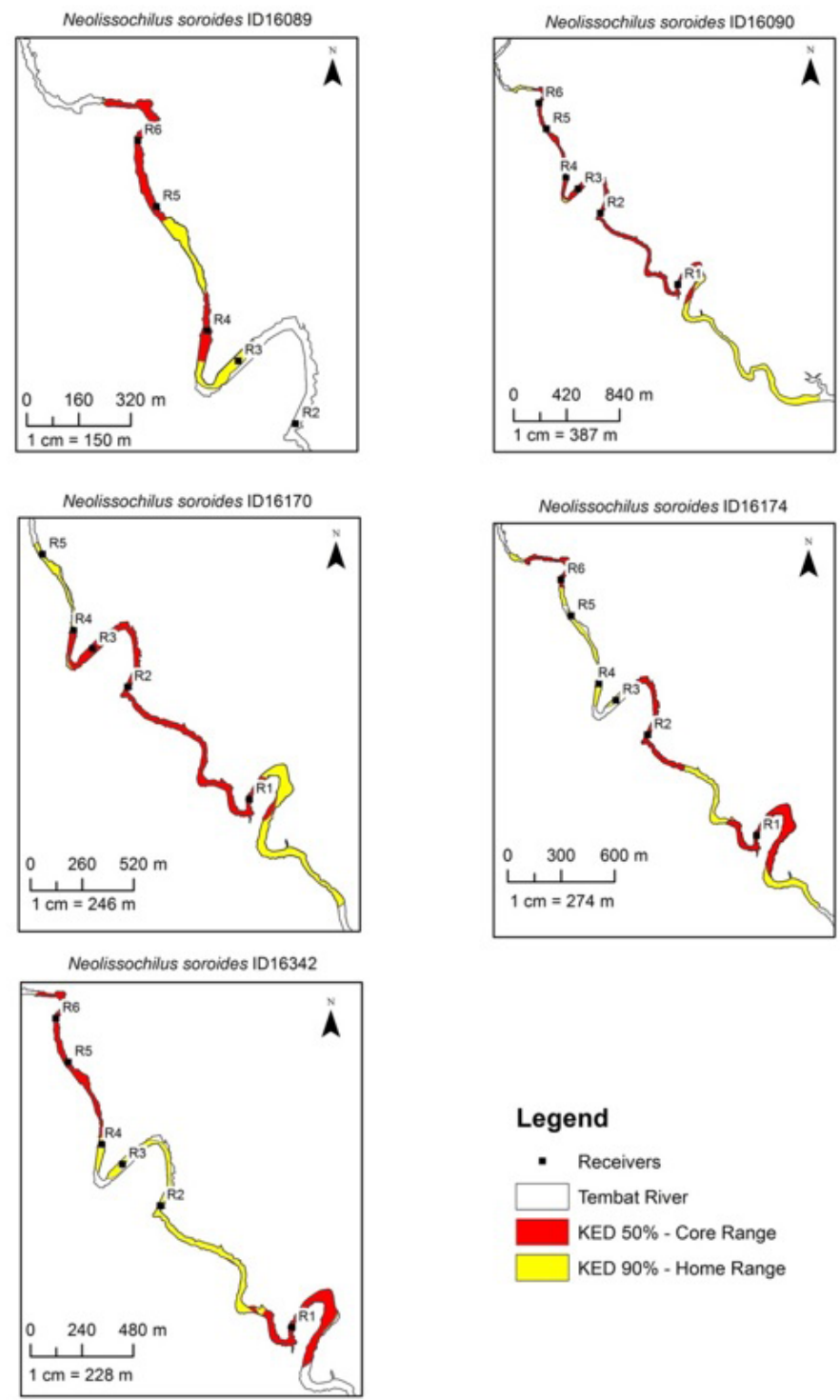

Figure 2. The kernel estimation density (KED) home range $90 \%$ (yellow) and core range 50\% (red) for individuals of Neolissochilus soroides in Tembat Reservoir from April to December 2018 
Shazana Sharir, Nurfatin Zulkipli, Azhari Mohamad, Farah Ayuni Farinordin, Shafiq Zakeyuddin, Abdullah Samat, Amir Shah Ruddin Md Sah and Shukor Md Nor
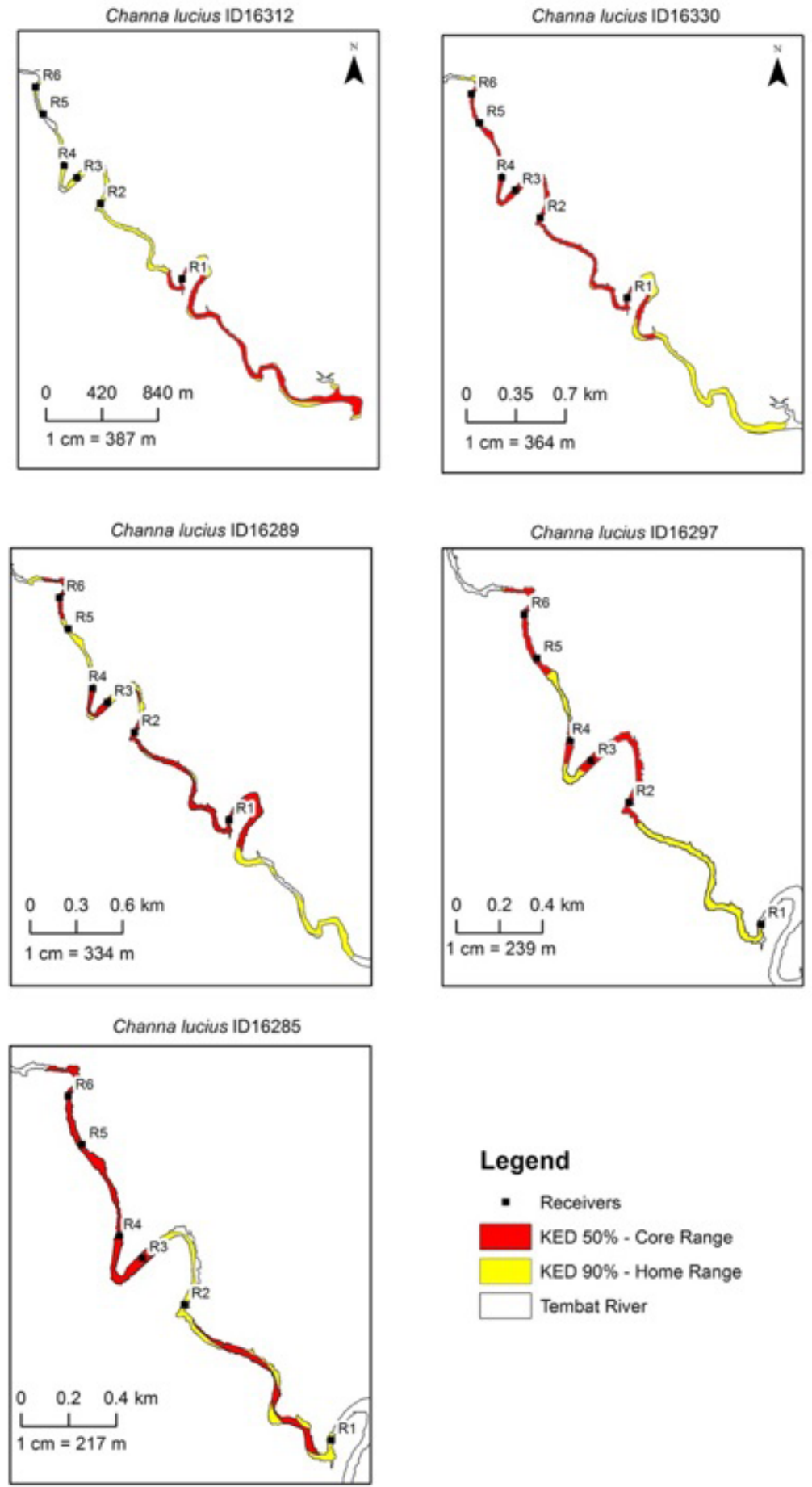

\section{Legend}

- Receivers

KED 50\% - Core Range

KED 90\% - Home Range

Tembat River

Figure 3. The kernel estimation density (KED) home range $90 \%$ (yellow) and core range 50\% (red) for Channa lucius in Tembat River from April to December 2018 
Table 2

The 50\% KED (core area) and 90\% KED (home range) by each of the individuals of both species in Tembat river from April to December 2018

\begin{tabular}{lccccc}
\hline Species & ID & $\begin{array}{c}\text { TL } \\
(\mathrm{cm})\end{array}$ & $\begin{array}{c}50 \% \text { KED mean } \\
\text { core area } \\
\left(\mathrm{m}^{2}\right)\end{array}$ & $\begin{array}{c}90 \% \text { KED } \\
\text { home range } \\
\text { area }\left(\mathrm{m}^{2}\right)\end{array}$ & $\begin{array}{c}\text { No. of } \\
\text { core area }\end{array}$ \\
\hline $\begin{array}{l}\text { Neolissochilus } \\
\text { soroides } \\
\begin{array}{l}\text { Neolissochilus } \\
\text { Soroides }\end{array}\end{array}$ & 16089 & 40 & $7657.5 \pm 3147.50$ & 28078 & 2 \\
$\begin{array}{l}\text { Neolissochilus } \\
\text { soroides }\end{array}$ & 16090 & 35 & $4128.2 \pm 1801.90$ & 155848 & 10 \\
$\begin{array}{l}\text { Neolissochilus } \\
\text { soroides }\end{array}$ & 16174 & 47.5 & $4266.73 \pm 3154.18$ & 103964 & 11 \\
$\begin{array}{l}\text { Neolissochilus } \\
\text { soroides }\end{array}$ & 16342 & 41.5 & $6880 \pm 3006.92$ & 85822 & 6 \\
$\begin{array}{l}\text { Channa lucius } \\
\text { Channa lucius }\end{array}$ & 16285 & 43 & $7940.10 \pm 2946.81$ & 103725 & 10 \\
$\begin{array}{l}\text { Channa lucius } \\
\text { Channa lucius }\end{array}$ & 16289 & 43 & $10470.70 \pm 9076.34$ & 131992 & 7 \\
Channa lucius & 16312 & 43 & $25556.63 \pm 21892.55$ & 161425 & 3 \\
\hline
\end{tabular}

Note. $\mathrm{KED}=$ Kernel estimation density

\section{Time Spent in Various Zones of Tembat} Reservoir

The average time spent by $N$. soroides and $C$. lucius at three different zones of the reservoir is shown in Figure 4. A one-way analysis of variance (ANOVA) conducted on the average time spent of $N$. soroides individuals resulted in a significant difference, $\mathrm{F}(5,576)=9.867, p<0.001$. In which further Tukey test showed time spent in R2 $(\mathrm{M}=2.71$ hours, $\mathrm{SE}=0.38)$ was significantly higher compared to R1 $(\mathrm{M}=1.30$ hours, $\mathrm{SE}=0.13), \mathrm{R} 3(\mathrm{M}=0.22$ hours, $\mathrm{SE}=0.09), \mathrm{R} 4(\mathrm{M}=0.98$ hours, $\mathrm{SE}$ $=0.27), \mathrm{R} 5(\mathrm{M}=1.04$ hours, $\mathrm{SE}=0.23)$, and R6 $(\mathrm{M}=0.46$ hours, $\mathrm{SE}=0.09)$. These results suggest that $N$. soroides spent more time at R2, which is at the transition zone of Tembat Reservoir. As for C. lucius, the average time spent between receivers locations also resulted in a significant difference, $\mathrm{F}(5,360)=12.489, p=0.001$. 
Tukey HSD test indicated that the average time spent at R5 $(\mathrm{M}=7.28$ hours, $\mathrm{SE}=$ 1.09) was significantly higher compared to the time spent at $\mathrm{R} 1(\mathrm{M}=1.78$ hours, $\mathrm{SE}=$ $0.20), \mathrm{R} 2(\mathrm{M}=1.95$ hours, $\mathrm{SE}=0.31), \mathrm{R} 3$ $(\mathrm{M}=2.16$ hours, $\mathrm{SE}=0.97), \mathrm{R} 4(\mathrm{M}=1.55$, $\mathrm{SE}=0.76)$, and $\mathrm{R} 6(\mathrm{M}=3.46, \mathrm{SE}=0.61)$. Tukey test also reveals that the average time spent at R6 was significantly higher than R1 and R2. Specifically, this result suggests that C. lucius spent more time at R5 and R6, the riverine zone, compared to the lacustrine and transition zone of Tembat Reservoir. This result indicates a difference in response of both species towards the newly inundated area in Tembat reservoir where C. lucius was avoiding, and $N$. soroides was approaching the area.

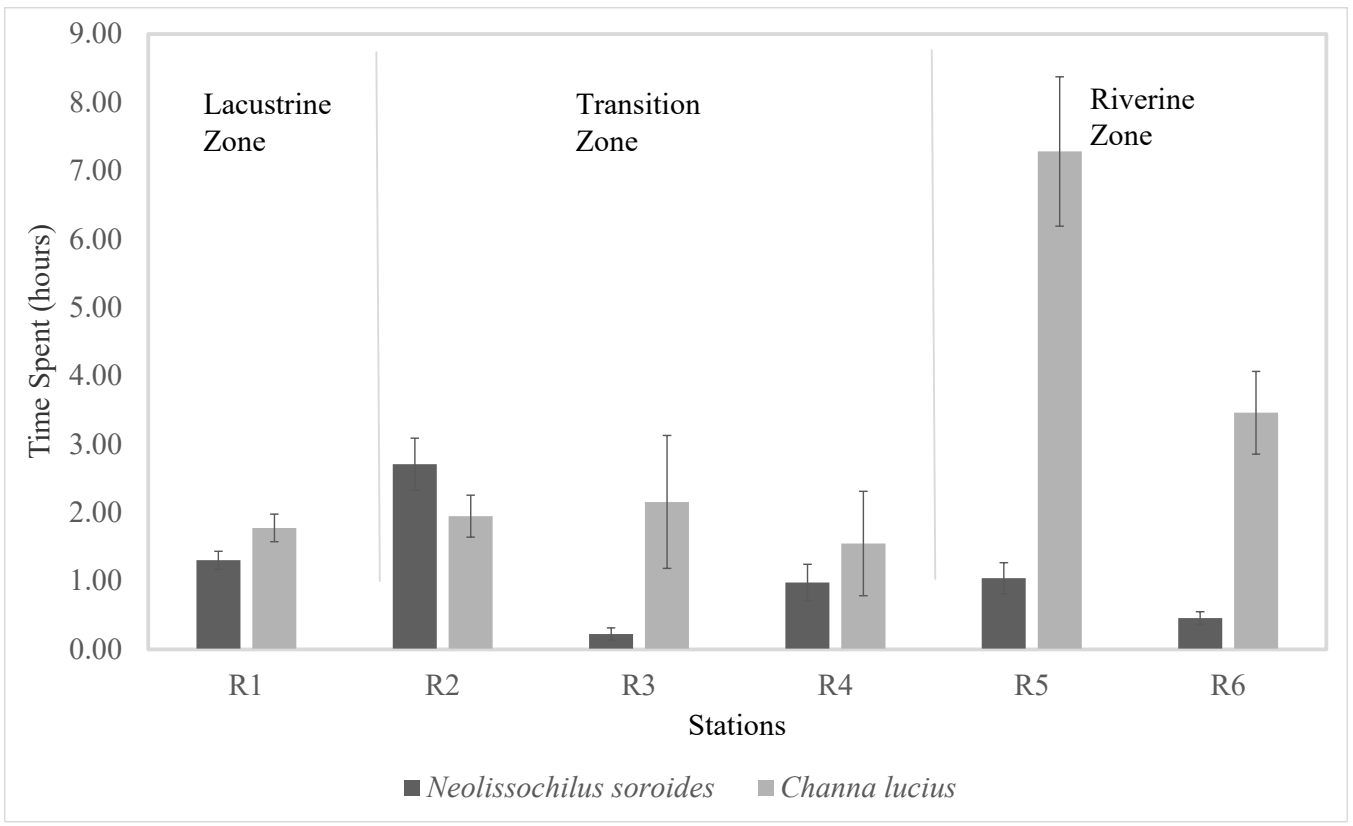

Figure 4. The time spent by Neolissochilus soroides and Channa lucius in the Tembat Reservoir system at different zones detected by the passive receivers (R1 - R6)

\section{Habitat Parameters Associated with Neolissochilus soroides and Channa lucius in Tembat Reservoir}

Based on the Kaiser-Guttman and broken stick model criteria, population components having eigenvalues greater than 1 represent shared variation and should be retained. For
$N$. soroides, the first three components were identified to have eigenvalues greater than 1: PC1, PC2, and PC3, explaining 62.32\% of the cumulative variance. PC1, PC2, and PC3 accounted for $29.70 \%, 18.03 \%$, and $14.58 \%$ of the variance, respectively. Meanwhile, for C. lucius, PCA identified 
the first four principal components to have and PC4 accounted for $29.07 \%, 16.03 \%$, an eigenvalue greater than $1 . \mathrm{PC} 1, \mathrm{PC} 2, \quad 15.29 \%$, and $10.80 \%$ of the variation, PC3, and PC4 jointly explained $71.19 \%$ of respectively (Table 3).

the cumulative variation. PC1, PC2, PC3,

\section{Table 3}

The eigenvalue for each component and percentage of variance explained for Neolissochilus soroides and Channa lucius, and bolded is the component retained

\begin{tabular}{|c|c|c|c|}
\hline Component & Eigenvalue & Variance $(\%)$ & $\begin{array}{c}\text { Cumulative variance } \\
(\%)\end{array}$ \\
\hline \multicolumn{4}{|c|}{ Neolissochilus soroides } \\
\hline 1 & 2.97 & 29.7 & 29.7 \\
\hline 2 & 1.8 & 18.03 & 47.73 \\
\hline 3 & 1.46 & 14.58 & 62.32 \\
\hline 4 & 0.86 & 8.62 & 70.94 \\
\hline 5 & 0.81 & 8.15 & 79.08 \\
\hline 6 & 0.71 & 7.1 & 86.19 \\
\hline 7 & 0.6 & 5.98 & 92.16 \\
\hline 8 & 0.42 & 4.17 & 96.33 \\
\hline 9 & 0.37 & 3.67 & 100 \\
\hline 10 & 0 & 0 & 100 \\
\hline \multicolumn{4}{|c|}{ Channa lucius } \\
\hline 1 & 2.91 & 29.07 & 29.07 \\
\hline 2 & 1.6 & 16.03 & 45.1 \\
\hline 3 & 1.53 & 15.29 & 60.39 \\
\hline 4 & 1.08 & 10.8 & 71.19 \\
\hline 5 & 0.93 & 9.26 & 80.45 \\
\hline 6 & 0.58 & 5.77 & 86.22 \\
\hline 7 & 0.56 & 5.57 & 91.79 \\
\hline 8 & 0.44 & 4.42 & 96.21 \\
\hline 9 & 0.34 & 3.37 & 99.58 \\
\hline 10 & 0.04 & 0.42 & 100 \\
\hline
\end{tabular}

In this study, the strongest association in each component were considered by the highest covariance. The $N$. soroides factor loadings matrix showed that the first principal component had the strongest association with distance to bank and river width $(r=0.97)$. Meanwhile, the second principal component had a strong association with canopy cover $(r=0.77)$, and the third principal component was highly associated with substrate type ( $r=$ 0.79). The C. lucius factor loadings matrix 
PCA indicated that the first principal While the third principal component had component had the strongest association the strongest association with the existence with mesohabitat type $(r=0.79)$. The second of canopy cover $(r=0.82)$, and the fourth principal component indicated the strongest principal component was strongly associated association with distance to riffle $(r=0.97)$. with elevation $(r=0.90)$ (Table 4).

Table 4

Loading matrix of the principal components with eigenvalue more than 1, Neolissochilus soroides with 4 habitat parameters and Channa lucius with also 4 habitat parameters

\begin{tabular}{|c|c|c|c|c|}
\hline \multirow{2}{*}{ Habitat parameters } & \multicolumn{4}{|c|}{ Neolissochilus soroides } \\
\hline & PC 1 & \multicolumn{2}{|c|}{ PC 2} & PC 3 \\
\hline Distance to bank & $0.97 *$ & \multicolumn{2}{|c|}{-0.03} & 0.11 \\
\hline River width & $0.97 *$ & \multicolumn{2}{|c|}{-0.03} & 0.11 \\
\hline Distance to riffle & 0.64 & \multicolumn{2}{|c|}{0.36} & 0.02 \\
\hline Canopy cover & 0.01 & \multicolumn{2}{|c|}{$0.77^{*}$} & -0.08 \\
\hline Depth & 0 & \multicolumn{2}{|c|}{0.66} & -0.33 \\
\hline $\begin{array}{l}\text { Submerge Large Wood } \\
\text { (SLW) }\end{array}$ & 0.02 & \multicolumn{2}{|c|}{0.64} & 0.46 \\
\hline Dist to lake & 0.18 & \multicolumn{2}{|c|}{0.54} & 0.34 \\
\hline Mesohabitat & 0.24 & \multicolumn{2}{|c|}{0.47} & 0.38 \\
\hline Substrate type & 0.06 & \multicolumn{2}{|c|}{-0.07} & $0.79 *$ \\
\hline Bank type & 0.07 & \multicolumn{2}{|c|}{0.06} & 0.73 \\
\hline \multirow{2}{*}{ Habitat parameters } & \multicolumn{4}{|c|}{ Channa lucius } \\
\hline & PC1 & $\mathrm{PC} 2$ & PC3 & $\mathrm{PC} 4$ \\
\hline Distance to bank & $0.79 *$ & 0.08 & 0.02 & -0.08 \\
\hline River width & 0.74 & 0.18 & -0.02 & -0.43 \\
\hline Distance to riffle & 0.70 & 0.17 & -0.19 & 0.37 \\
\hline Canopy cover & 0.55 & 0.2 & 0.24 & -0.39 \\
\hline Depth & 0.5 & -0.17 & -0.28 & 0 \\
\hline $\begin{array}{l}\text { Submerge Large Wood } \\
\text { (SLW) }\end{array}$ & 0.05 & $0.97 *$ & -0.03 & -0.07 \\
\hline Dist to lake & -0.14 & -0.96 & 0.11 & 0.05 \\
\hline Mesohabitat & -0.13 & -0.05 & $0.82 *$ & 0.14 \\
\hline Substrate type & 0 & -0.09 & 0.80 & -0.11 \\
\hline Bank type & -0.08 & -0.06 & 0.06 & 0.90 \\
\hline
\end{tabular}

Note. * Variable with the highest correlation with the principal component 


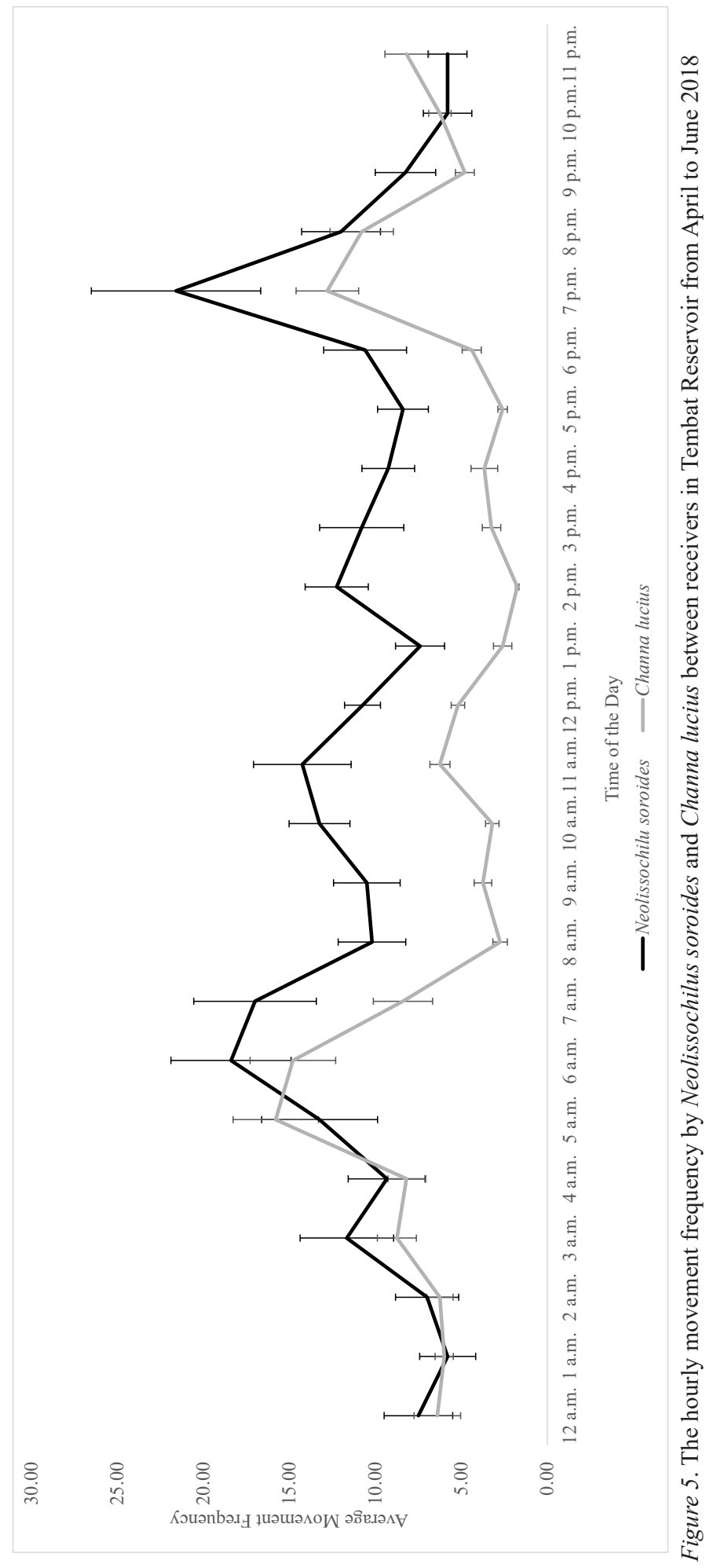

Pertanika J. Trop. Agric. Sci. 44 (3): 503 - 526 (2021) 
Shazana Sharir, Nurfatin Zulkipli, Azhari Mohamad, Farah Ayuni Farinordin, Shafiq Zakeyuddin, Abdullah Samat, Amir Shah Ruddin Md Sah and Shukor Md Nor

Activity Pattern of Neolissochilus soroides and Channa lucius

The 24-hour average movement frequency of $N$. soroides and C. lucius is shown in Figure 5. Both species show high-frequency movement during dawn and dusk. Whereby, $N$. soroides showed two high peaks of movement frequency at 6 a.m. $(\mathrm{M}=3.50$, $\mathrm{SE}=16.52)$, and 7 p.m. $(\mathrm{M}=21.6, \mathrm{SE}=$ 4.93). As for C. lucius, two high peaks of movement frequency were observed at 5 a.m. $($ mean $=15.8, \mathrm{SE}=2.48)$, and 7 p.m. $($ mean $=12.8, \mathrm{SE}=1.82)$.

No significant difference between daytime and nighttime movement for $N$. soroides were recorded. However, for C. lucius, three out of five individuals had significant differences between their daytime and nighttime movement: ID $16330[\mathrm{t}(32.658)=12, p=0.021]$, ID 16297 $[\mathrm{t}(-2.539)=12, p=0.036]$ and ID 16289 $[\mathrm{t}(-2.829)=12, p=0.015]$, which may indicate that this species make long-distance movements during night time.

\section{DISCUSSION}

\section{Home and Core Range of Neolissochilus soroides and Channa lucius}

The home range is commonly defined as where animals move from day to day (Hayne, 1949). This study defined the home range as to where the fish was detected and where it travels daily. In addition, the core area is defined to emphasise sections in a home range where the animal spends the greatest amount of time (Vander Wal \& Rodgers, 2012). This study is the first study to document the movement pattern and home range of $N$. soroides and $C$. lucius in the freshwater environment in Malaysia using the acoustic telemetry method.

In this study, the home range size of $N$. soroides and C. lucius were similar, indicating that both species shared the same pathway. It is highly contributed to the morphology of the Tembat River that does not have many tributaries or small streams (TNBR, 2007). The river system runs on a nearly straight path and is not a complex river system compared to the neighbouring Puah catchment river system. Tembat River system is river order 3 and can be considered a small system that runs $45 \mathrm{~km}$ from the headwater (TNBR, 2007). Despite the similar average home range size between $N$. soroides and C.lucius, individual ID 16089 ( $N$. soroides) had the smallest home range size $\left(27.79 \mathrm{~m}^{2}\right)$ compared to other individuals. This individual was never found in the lacustrine zone and was recorded by R3, R4, R5, R6, and the upper stream of the R6 area. Comparing to the congeners, Lapointe et al. (2013) recorded the Channa argus home range in the Potomac River, USA, having approximately 60 times larger than C. lucius in this study. According to Woolnough et al. (2009), the size of the river system and the size of the fish influence the home range estimates regardless of linear type or areal type of home range.

As for $N$. soroides, a comparable species would be of the mahseer species. Neolissochilus soroides to coexist with Tor species in the Tembat River and Tiang River (Mohamad et al., 2020; Pinder et al., 2019; Sharir et al., 2019). A recent study on the 
migration of Tor putitora and Neolissochilus haxaganolepis were conducted in Bhutan [Fisheries Conservation Foundation (FCF), 2019] recorded a larger home range size (more than $40 \mathrm{~km}$ distance) for these species compared to the findings in this study. Compared to its congener, a smaller home range of $N$. soroides and $C$. lucius reflects the smaller river system (Lonzarich et al., 2000). Larger systems are lesser geomorphic confining, thus allowing larger movement to be made as opposed to $N$. soroides in Tembat (Lonzarich et al., 2000).

Although there is no significant difference in the core area sizes, the variation in sizes observed cumulatively in the core area suggests that every individual movement is different in the ability or motivation to return to an area after moving throughout the river (Crook, 2004). A larger core area may indicate a territorial or predatory behaviour exhibited sporadically throughout the reservoir system (Figure 2 and Figure 3). The area highlighted in red is likely to be essential for each species, respectively. This area should be closely monitored to determine the importance of $N$. soroides and C. lucius. Food availability and predation risk may affect the motivation for an individual to have a different location of core area within the Tembat reservoir (Crook, 2004).

\section{Time Spent in Various Zones of Tembat Reservoir}

Channa lucius spent more time in the riverine zone, where the lotic system still influenced the area, and habitat heterogeneity is well preserved. This area provides sources of water inflow for the Tembat Reservoir and is not influenced by the outflow or dam operation. Mesohabitat characteristics such as pools and riffles are still present within the riverine zone. Furthermore, the existence of a fish sanctuary developed by Tenaga Nasional Berhad Research (TNBR) at the R5 (within the riverine zone) may be the reason for the significantly longer time spent by $C$. lucius in this area (Mohamad et al., 2020). Channa lucius is known as an ambush predator, which preys upon juvenile fishes abundance at R5. R5 provides a food source for C. lucius and shelter as the area was abundant with submerging large wood.

Neolissochilus soroides spent more time in the transition zone, converted into a nearly lentic system. The inundation of the Tembat River has created a trophic surge from the decomposed terrestrial vegetation, which usually increases the abundance and biomass of organisms utilising available resources (Arantes et al., 2019). These conditions may have become favourable to forage, and the availability of refuge may explain the significant amount of time spent in the area by $N$. soroides. The average depth in the transition zone, where $N$. soroides was found, was within the depth range where dissolved oxygen was still available (littoral zone). The littoral environment is known to have the highest biodiversity due to greater availability and heterogeneity of feeding resources, shelter, and habitat (Agostinho et al., 2008).

The age of the reservoir may become a significant factor for the utilisation by $N$. soroides and others ichthyofauna at the 
transition zone of the Tembat reservoir, as it is spatially and temporally dynamic (Tian et al., 2020). The freshwater fish community is more influenced by the type of mesohabitat structure available in the river than catchment-scale processes, such as the logging history of the adjacent area (Wilkinson et al., 2018). However, the period since the logging activity correlates positively to the abundance of common cyprinids (Martin-Smith, 1998). Therefore, nutrient and food resources will likely deplete, and trophic structure collapse is predicted. A future survey in the transition and lacustrine zone should be conducted to observe the reservoir's impact and put mitigation measures into action.

\section{Habitat Parameters Associated with Neolissochilus soroides and Channa lucius in Tembat Reservoir}

Four habitat parameters were highly associated with $N$. soroides and C. lucius detection in Tembat Reservoir. However, only one parameter was similar between the species: the existence of canopy cover. Certainly, canopy cover protects fish from the glaring sun, maintain water temperature, and refuge from areal predators, such as birds of prey (Ceschin et al., 2015; Rutherford et al., 1997). However, it is noteworthy that most of the vegetation fringing the river in the Tembat catchment was wiped out during logging activity before the construction phase. As a result, the remains of riparian vegetation were scarce, but it remained the habitat that both of the species were detected. Thus, indicating the crucial role of riparian vegetation for the ichthyofauna in Tembat Reservoir.

Mesohabitat type was an important habitat characteristic in the detection of $C$. lucius in Tembat Reservoir. This species was commonly detected in the river run during the active daytime tracking. The river in the area studied was characterised by submerging large woods from the logging activity during the construction phase. It is assumed that C. lucius benefited from these structures for camouflage and shelter during the day. Several reports from this region also recorded a similar finding of $C$. lucius in submerged woody plants and aquatic vegetation area (Azrita, 2010; Rainboth, 1996).

Distance to riffle was one of the important habitat characteristics identified by PCA for $C$. lucius. This species was detected at an average of $846.14 \mathrm{~m} \pm$ $95.43 \mathrm{~m}$ from the nearest riffle. Comparing this finding with $N$. soroides, which were detected at an average of $630.70 \mathrm{~m} \pm$ $64.30 \mathrm{~m}$, C. lucius showed preferences further from faster-moving water. This is supported by the predatory behaviour of Channa species that have been recorded to habituate slow-moving rivers (Rainboth, 1996). Elevation was also identified by PCA to be highly associated with C. lucius detection in component 4. However, this parameter was the least concern in this study area because the range of elevation was not much of a difference, which was supported by the indifference velocity at all locations detected (data unpublished). 
As for $N$. soroides, distance to bank and river width was the most important characteristics identified by PCA. These two parameters can be perceived as the size of the river because the distance to a bank can not exceed the river width. The size of the river plays a vital role in the detection of $N$. soroides and generally mahseer species. Neolissochilus soroides and other mahseer species are commonly found in the upper part of a river where the size of the river is relatively small (15-35 $\mathrm{m}$ wide) (Ambak et al., 2012; Khaironizam, 2010; Walton et al., 2017). In addition, the upper river supports the morphology and the physiological needs of mahseer, such as cooler water temperature, a more heterogeneous habitat (existence of pools, riffles, and runs), and food sources, such as algae and mayflies on the coarse river bed. Finally, substrate type was identified as one of the vital habitat parameters for $N$. soroides. During this study, $N$. soroides were commonly found on substrate type sand. It was not surprising as most of the river beds of Tembat River were smothered by sand and siltation due to the previous land clearing at the riparian area. The changes of river bed substrate are predicted to alter the foraging behaviour for not only $N$. soroides but other freshwater species, including invertebrates. Mahseer species are also known to spawn at the upper river with a coarse substrate such as cobbles and pebbles.

The type of habitat parameters associated with these two species can be a key habitat factor in establishing or identifying an area to be protected. For example, an area with submerged large wood should be protected by not removing or extracting the structure from the river. This area provides protection but also create the dynamic of hydrology that is essential for fish (Baillie et al., 2013). Based on this finding, removing riparian vegetation is not encouraged, and replanting of this area is needed.

\section{Activity Pattern of Neolissochilus soroides and Channa lucius}

Channa lucius exhibited nocturnal characteristics based on the movement behaviour detected by VR $2 \mathrm{~W}$ receivers deployed. During nighttime observation in Tembat Reservoir, C. lucius was often seen at the fringe of the river during dusk, in which it was hunting for juvenile fishes. Similarly, Horký et al. (2008) reported that Sander lucioperca, a European predatory freshwater species, were also found actively hunting for food at night. Channa lucius activity in the Tembat Reservoir appeared to be in line with its congener and other facultative air-breathing species that appear to be active at night (Boujard, 1995; Guo et al., 2017). Although N. soroides exhibit twomovement activity peaks during nighttime, they were not considered a nocturnal species. There were no significant differences in the individual average nighttime and daytime movement. These findings are supported by studies in Khaironizam (2010) that show $N$. soroides diurnally active and foraged during daylight based on the findings of the gut content. The movement recorded during the survey was the movement of the individual from one receiver to another receiver. 
Therefore, it was considered a longdistance movement, as the passive trackers were deployed at least 200 meters from each other. Long-distance movement during the daytime may increase the risk of predation for fish by other species, such as birds, otters, and large fish (Shoji et al., 2017). This situation could explain the tendency in both species to make long-distance movements during nighttime to avoid predation. Time of day is one of the many factors that influence the movement of a fish for it to meet its metabolic or sheltering needs (Albanese et al., 2004). Many classical studies on the diel activity pattern of fish were associated with observations of feeding behaviour, as feeding is one of the main motivations of the fish to move from one place to another (Boujard, 1995; Clough \& Ladle, 1997; Khaironizam, 2010; Weliange et al., 2006).

\section{CONCLUSION}

Channa lucius and Neolissochilus soroides utilise the same areas throughout the zones of Tembat Reservoir, which is most likely due to the non-complex river system. However, the zones in which the species prefer to stay longer were different, whereby $N$. soroides in the transition zone and C. lucius in the riverine zone may be motivated by the availability of specific food resources for each species. Neolissochilus soroides detection in Tembat Reservoir was highly associated with the size of the river, and the availability of canopy, cover and riverbed substrate, while C. lucius were four mesohabitat types, the distance to riffle, the availability of canopy cover and elevation.
These key habitat parameters identified should be applied in the conservation management of an altered river in Tembat Reservoir. The 24-hour movement activity pattern recorded two peak hours during dusk and dawn for both species, further investigating for foraging and predator avoidance behaviour. Monitoring of habitat utilisation by fish fauna in the system should be conducted as the reservoir ages, especially in the inundated area where the ecosystem changes.

\section{ACKNOWLEDGMENTS}

The authors would like to thank Tenaga Nasional Berhad Research for the workforce, facility, and cooperation provided to conduct this research. In addition, Universiti Kebangsaan Malaysia has supported this work (Grant No.: ST-2017-007).

\section{REFERENCES}

Agostinho, A. A., Pelicice, F. M., \& Gomes, L. C. (2008). Dams and the fish fauna of the Neotropical region: Impacts and management related to diversity and fisheries. Brazilian Journal of Biology, 68(4), 1119-1132. https:// doi.org/10.1590/S1519-69842008000500019

Albanese, B., Angermeier, P. L., \& Dorai-Raj, S. (2004). Ecological correlates of fish movement in a network of Virginia streams. Canadian Journal of Fisheries and Aquatic Sciences, 61(6), 857-869. https://doi.org/10.1139/F04-096

Ambak, M. A., Mat Isa, M., Zaidi, M. Z., \& Mazlan, A. G. (2012). Fishes of Malaysia. Penerbit Universiti Malaysia Terengganu.

Arantes, C. C., Fitzgerald, D. B., Hoeinghaus, D. J., \& Winemiller, K. O. (2019). Impacts of 
hydroelectric dams on fishes and fisheries in tropical rivers through the lens of functional traits. Current Opinion in Environmental Sustainability, 37, 28-40. https://doi. org/10.1016/j.cosust.2019.04.009

Asaad, I., Lundquist, C. J., Erdmann, M. V., \& Costello, M. J. (2017). Ecological criteria to identify areas for biodiversity conservation. Biological Conservation, 213(Part B), 309-316. https://doi.org/10.1016/j.biocon.2016.10.007

Azrita. (2010). Parameter fisika, kimia dan biologi penciri habitat ikan bujuk (Channa lucius, Channidae) [Physical, chemical and biological parameters characterizing the habitat of persuasive fish (Channa lucius, Channidae)]. http://fpik.bunghatta.ac.id/files/downloads/ Seminar\%20Nasional/Prosiding/azrita.pdf

Azrita, A., Basri, Y., \& Syandri, H. (2015). EA preliminary study on domestication of bluespotted snakehead (Channa lucius, Channidae) in concrete tank. Journal of Aquaculture Research and Development, 6(2), 1000309. https://doi. org/10.4172/2155-9546.1000309

Baillie, B. R., Hicks, B. J., van den Heuvel, M. R., Kimberley, M. O., \& Hogg, I. D. (2013). The effects of wood on stream habitat and native fish assemblages in New Zealand. Ecology of Freshwater Fish, 22(4), 553-566. https://doi. org/10.1111/eff.12055

Baltz, D. (1990). Autoecology. In C. Schreck \& P. Moyle (Eds.), Methods for fish biology (pp. 593-598). American Fisheries Society.

Boujard, T. (1995). Diel rhythms of feeding activity in the European catfish, Silurus glanis. Physiology and Behavior, 58(4), 641-645. https://doi. org/10.1016/0031-9384(95)00109-V

Ceschin, S., Tombolini, I., Abati, S., \& Zuccarello, V. (2015). The effect of river damming on vegetation: Is it always unfavourable? A case study from the River Tiber (Italy). Environmental Monitoring and Assessment, 187(5). https://doi. org/10.1007/s10661-015-4521-7
Clarke, A. D., Telmer, K. H., \& Shrimpton, J. M. (2007). Habitat use and movement patterns for a fluvial species, the Arctic grayling, in a watershed impacted by a large reservoir: Evidence from otolith microchemistry. Journal of Applied Ecology, 44(6), 1156-1165. https:// doi.org/10.1111/j.1365-2664.2007.01350.x

Clough, S., \& Ladle, M. (1997). Diel migration and site fidelity in a stream-dwelling cyprinid, Leuciscus leuciscus. Journal of Fish Biology, 50(5), 1117-1119. https://doi.org/10.1006/ jfbi.1996.0360

Crook, D. A. (2004). Is the home range concept compatible with the movements of two species of lowland river fish?. Journal of Animal Ecology, 73(2), 353-366. https://doi.org/10.1111/j.00218790.2004.00802.x

Dolloff, C. A., \& Warren, M. L. (2003). Fish relationships with large wood in small streams. American Fisheries Society Symposium, 37, 179-193.

Fearnside, P. M. (2014). Impacts of Brazil's Madeira River Dams: Unlearned lessons for hydroelectric development in Amazonia. Environmental Science and Policy, 38, 164-172. https://doi. org/10.1016/j.envsci.2013.11.004

Fetterplace, L. C., Davis, A. R., Neilson, J. M., Taylor, M. D., \& Knott, N. A. (2016). Active acoustic tracking suggests that soft sediment fishes can show site attachment: A preliminary assessment of the movement patterns of the blue-spotted flathead (Platycephalus caeruleopunctatus). Animal Biotelemetry, 4(1), 15. https://doi. org/10.1186/s40317-016-0107-6

Fisheries Conservation Foundation. (2019). Mahseer research project: Final report. Ministry of Agriculture and Forest Royal Government of Bhutan.

Frontier, S. (1976). Étude de la décroissance des valeurs propres dans une analyse en composantes principales: Comparaison avec le modd́le du 
Shazana Sharir, Nurfatin Zulkipli, Azhari Mohamad, Farah Ayuni Farinordin, Shafiq Zakeyuddin, Abdullah Samat, Amir Shah Ruddin Md Sah and Shukor Md Nor

bâton brisé [Study of the decay of eigenvalues in a principal component analysis: Comparison with the broken stick model]. Journal of Experimental Marine Biology and Ecology, 25(1), 67-75. https://doi.org/10.1016/00220981(76)90076-9

Guo, Z., Liu, J., Lek, S., Li, Z., Zhu, F., Tang, J., Britton, R., \& Cucherousset, J. (2017). Coexisting invasive gobies reveal no evidence for temporal and trophic niche differentiation in the sublittoral habitat of Lake Erhai, China. Ecology of Freshwater Fish, 26(1), 42-52. https://doi.org/10.1111/eff.12249

Guttman, L. (1954). Some necessary conditions for common-factor analysis. Psychometrika, 19(2), 149-161. https://doi.org/10.1007/BF02289162

Hayne, D. W. (1949). Calculation of size of home range. Journal of Mammalogy, 30(1), 1-18. https://doi.org/10.2307/1375189

Horký, P., Slavík, O., \& Bartoš, L. (2008). A telemetry study on the diurnal distribution and activity of adult pikeperch, Sander lucioperca (L.), in a riverine environment. Hydrobiologia, 614(1), 151-157. https://doi.org/10.1007/s10750-0089503-0

Huang, L., \& Li, J. (2016). Status of freshwater fish biodiversity in the Yangtze River Basin, China. In S.-I. Nakano, T. Yahara, \& T. Nakashizuka (Eds.), Aquatic biodiversity conservation and ecosystem services (pp. 13-30). Springer International Publishing. https://doi.org/10.1007/978-98110-0780-4_2

Jackson, D. A. (1993). Stopping rules in principal components analysis: A comparison of heuristical and statistical approaches. Ecology, 74(8), 22042214. https://doi.org/10.2307/1939574

Kano, Y., Dudgeon, D., Nam, S., Samejima, H., Watanabe, K., Grudpan, C., Grudpan, J., Magtoon, W., Musikasinthorn, P., Nguyen, P. T., Praxaysonbath, B., Sato, T., Shibukawa,
K., Shimatani, Y., Suvarnaraksha, A., Tanaka, W., Thach, P., Tran, D. D., Yamashita, T., \& Utsugi, K. (2016). Impacts of dams and global warming on fish biodiversity in the Indo-Burma hotspot. PLOS One, 11(8), e0160151. https://doi. org/10.1371/journal.pone.0160151

Khai, N. X., Kusairi, M. N., Ahmad, S., Syahaneem, M. Z., \& Fatimah, M. A. (2015). Market potential analysis for tengas (Neolissochilus sp.) in the Malaysian market. International Food Research Journal, 22(4), 1429-1432.

Khaironizam, M. Z. (2010). Some biological aspects of Neolissochilus spp. (Teleostel: Cyprinidae) from Peninsular Malaysia. Penerbit Universiti Malaya.

Khaironizam, M. Z., Zakaria-Ismail, M., \& Armbruster, J. W. (2015). Cyprinid fishes of the genus Neolissochilus in Peninsular Malaysia. Zootaxa, 3962(1), 139-157. https:// doi.org/10.11646/zootaxa.3962.1.7

Kimmel, B. L., \& Groeger, A. W. (1984). Factors controlling primary production in lakes and reservoirs: A perspective. Lake and Reservoir Management, 1(1), 277-281. https://doi. org/10.1080/07438148409354524

Laffan, S. W., \& Taylor, M. D. (2013, 1-6 December). FishTracker: A GIS toolbox for kernel density estimation of animal home ranges that accounts for transit times and hard boundaries. Proceedings - 20th International Congress on Modelling and Simulation, Adelaide, Australia. https://oi.org/10.36334/modsim.2013.h2.laffan

Lapointe, N. W. R., Odenkirk, J. S., \& Angermeier, P. L. (2013). Seasonal movement, dispersal, and home range of northern snakehead Channa argus (Actinopterygii, Perciformes) in the Potomac River catchment. Hydrobiologia, 709, 73-87. https://doi.org/10.1007/s10750-012-1437-x

Li, X., Li, Y. R., Chu, L., Zhu, R., Wang, L. Z., \& Yan, Y. Z. (2016). Influences of local habitat, tributary position, and dam characteristics 
on fish assemblages within impoundments of low-head dams in the tributaries of the Qingyi River, China. Zoological Research, 37(2), 67-74. https://doi.org/10.13918/j.issn.20958137.2016.2.67

Lonzarich, D. G., Lonzarich, M. R., \& Warren, J. (2000). Effects of riffle length on the shortterm movement of fishes among stream pools. Canadian Journal of Fisheries and Aquatic Sciences, 57(7), 1508-1514. https://doi. org/10.1139/f00-082

Martin-Smith, K. M. (1998). Effects of disturbance caused by selective timber extraction on fish communities in Sabah, Malaysia. Environmental Biology of Fishes, 53(2), 155-167. https://doi. org/10.1023/A:1007496424730

Mohamad, A., Sharir, S., Farinordin, F. A., Zakeyuddin, M. S., Shukor, A. M., Samat, A., \& Nor, S. M. (2020). Length-weight relationship and relative condition factor of Tor tambra in Tembat Reservoir, Terengganu, Peninsular Malaysia: Indication of environmental health. In L. Mohd Sidek, G. H. A. Salih, \& M. H. Boosroh (Eds.), International Conference on Dam Safety Management and Engineering (pp. 447-456). Springer Singapore.

Pinder, A. C., Britton, J. R., Harrison, A. J., Nautiyal, P., Bower, S. D., Cooke, S. J., Lockett, S., Everard, M., Katwate, U., Ranjeet, K., Walton, S., Danylchuk, A. J., Dahanukar, N., \& Raghavan, R. (2019). Mahseer (Tor spp.) fishes of the world: Status, challenges and opportunities for conservation. Reviews in Fish Biology and Fisheries, 29(2), 417-452. https://doi. org/10.1007/s11160-019-09566-y

Rainboth, W. J. (1996). Fishes of the Cambodian Mekong. Food And Agriculture Organization of The United Nations.

Rutherford, J. C., Blackett, S., Blackett, C., Saito, L., \& Davies-Colley, R. J. (1997). Predicting the effects of shade on water temperature in small streams. New Zealand Journal of Marine and Freshwater Research, 31(5), 707-721. https:// doi.org/10.1080/00288330.1997.9516801

Schmutz, S., \& Moog, O. (2018). Dams: Ecological impacts and management. In S. Schmutz \& J. Sendzimir (Eds.), Riverine ecosystem management: Science for governing towards a sustainable future (pp. 111-127). Springer International Publishing. https://doi. org/10.1007/978-3-319-73250-3_6

Sharir, S., Mohamad, A., Zakeyuddin, S., Samat, A., Close, P., \& Shukor, M. N. (2019). Ichtyofaunal diversity of Tiang River in Royal Belum Forest Reserve, Malaysia. Malayan Nature Journal, 71(4), 391-400.

Shoji, J., Mitamura, H., Ichikawa, K., Kinoshita, H., \& Arai, N. (2017). Increase in predation risk and trophic level induced by nocturnal visits of piscivorous fishes in a temperate seagrass bed. Scientific Reports, 7(1), 1-10. https://doi. org/10.1038/s41598-017-04217-3

Tenaga Nasional Berhad Research. (2007). Detailed environmental impact assesment. TNBR.

Tian, K., Yang, W., Zhao, Y. W., Yin, X. A., Cui, B. S., \& Yang, Z. F. (2020). Development of a hydrological boundary method for the river-lake transition zone based on flow velocity gradients, and case study of Baiyangdian Lake transition zones, China. Water, 12(3), 1-23. https://doi. org/10.3390/w12030674

Vander Wal, E., \& Rodgers, A. R. (2012). An individual-based quantitative approach for delineating core areas of animal space use. Ecological Modelling, 224(1), 48-53. https://doi. org/10.1016/j.ecolmodel.2011.10.006

Walton, S. E., Gan, H. M., Raghavan, R., Pinder, A. C., \& Ahmad, A. (2017). Disentangling the taxonomy of the mahseers (Tor spp.) of Malaysia : An integrated approach using morphology, genetics and historical records disentangling the taxonomy of the mahseers (Tor spp.) of Malaysia. Reviews in Fisheries Science 
Shazana Sharir, Nurfatin Zulkipli, Azhari Mohamad, Farah Ayuni Farinordin, Shafiq Zakeyuddin, Abdullah Samat, Amir Shah Ruddin Md Sah and Shukor Md Nor

and Aquaculture, 25(3), 171-183. https://doi.or $\mathrm{g} / 10.1080 / 23308249.2016 .1251391$

Weber, E. P. S., Weisse, C., Schwarz, T., Innis, C., \& Klide, A. M. (2009). Anesthesia, diagnostic imaging, and surgery of fish. Compendium: Continuing Education for Veterinarians, 31(2), E11.

Weliange, W. S., Amarasinghe, U. S., Moreau, J., \& Villanueva, M. C. (2006). Diel feeding periodicity, daily ration and relative food consumption in some fish populations in three reservoirs of Sri Lanka. Aquatic Living Resources, 19(3), 229-237. https://doi.org/10.1051/alr:2006023

Wilkinson, C. L., Yeo, D. C. J., Tan, H. H., Fikri, A. H., \& Ewers, R. M. (2018). Land-use change is associated with a significant loss of freshwater fish species and functional richness in Sabah, Malaysia. Biological Conservation, 222, 164-171. https://doi.org/10.1016/j. biocon.2018.04.004

Woolnough, D. A., Downing, J. A., \& Newton, T. J. (2009). Fish movement and habitat use depends on water body size and shape. Ecology of Freshwater Fish, 18(1), 83-91. https://doi. org/10.1111/j.1600-0633.2008.00326.x
Zafirah, N., Nurin, N. A., Samsurijan, M. S., Zuknik, M. H., Rafatullah, M., \& Syakir, M. I. (2017). Sustainable ecosystem services framework for tropical catchment management: A review. Sustainability, 9(4), 546-571. https://doi. org/10.3390/su9040546

Zeiringer, B., Seliger, C., Greimel, F., \& Schmutz, S. (2018). River hydrology, flow alteration, and environmental flow. In S. Schmutz \& J. Sendzimir (Eds.), Riverine ecosystem management: Science for governing towards a sustainable future (pp. 67-89). Springer International Publishing. https://doi.org/10.1007/978-3-319-73250-3_4

Zhong, Y., \& Power, G. (1996). Environmental impacts of hydroelectric projects on fish resources in China. Regulated Rivers: Research and Management, 12(1), 81-98. https://doi.org/10.1002/ (SICI)1099-1646(199601)12:1<81::AIDRRR378>3.0.CO;2-9 